\title{
DESCRIPTIONS OF NEW SPECIES OF ARCTIANAE IN THE TRING MUSEUM.
}

\author{
By The hon. Walter Rothschild, Рh.D.
}

\section{Ecpantheria kennedyi spec. nov.}

o. Similar to mus Oberth. but larger. Differs as follows : pectus black, not white; legs deep steel-blue with six narrow whitish bands, not white with nine or ten black bands; palpi black, not white; head pale grey, not white; tegnlae grey, not white; two steel-blue lines start from a common point some distance from base forming a $\mathrm{V}$ on each tegula, not two widely separated parallel lines starting from base; patagia steel-blue with monse-grey borders, not greyish white with two parallel black lines; thorax grey with two steel-blue parallel bands, not greyish-white with four hair lines. Abdomen, basal three segments and anal segment white, rest steel-blue._-Forewing semihyaline white, basal one-third, inner area to vein 2 and costal area pale grey, not white; spots on costal and inner areas larger, grey, not white, with distinct much broader steel-blue borders, not hair-like black ones.—Hindwing white.

Mab. Preto, Minas Geraës.

1 o.

\section{Ecpantheria mus brasiliensis subspec. nov.}

o. Similar to mus mus, but larger, and ground-colour grey, not white; markings more pronounced.

+. Ground-colour of forewings monse-grey, not white.

Hab. Castro, Parana, Brazil, July 1897 (Type) (E. D. Jones); Sapucay, Paraguay, October 1902 (W. Foster); Corcovado.

6 oิ ô, 7 우우.

\section{Ecpantheria magdalenae steinbachi subspec. nov.}

o. Similar to $m$. magdalenae but much larger, and the three discal bands of dark patches on forewings closer together, owing to the innermost one being farther from the base.—Hindwing more suffused with orange, tail longer and wider. Abdomen much blacker above, owing to the black bands being wider and longer.

Hab. Buenavista, E. Bolivia (J. Steinbach).

3 oิ ô.

\section{Ecpantheria burmeisteri spec. nov.}

o. Nearest allied to kinkelini Burm. Pectus brown-grey; palpi buff; frons black; head creamy white; antennae black; thorax white, a grey-brown dot on tegulae, two grey-brown spots ringed with black on patagia, two blue-black spots at juncture with abdomen; abdomen scarlet, two lines of steel-blue dorsal patches, last segment but one dorsally blue-black, anal segment above bluish brown, basal segment white, centrally brown._- Forewing : basal two-thirds white with four transverse rows of brown-grey patches ringed with black, onter one-third hyaline with two indistinct similar rows.-Hindwing semihyaline white, two minute dusky dots at tornus. 
․ Much larger, whole forewing pinkish white with seven very distinct transverse rows of patches._- Hindwing white with irregular rows and patches of dark grey. Abdomen differs in the steel-blue patches being larger and grey ringed with steel-blue; on second segment the two patches are united into one large patch.

Length of forewing : ô $24 \mathrm{~mm}$. ; + $29 \mathrm{~mm}$.

Hab. Tucuman (J. Steinbach).

1 ô, 4 우우.

\section{Ecpantheria dognini spec. nov.}

Allied to robusta Dogn., but differs as follows : ô smaller; pectus white, not steel-blne; palpi brown with white margin, not steel-blue with only first joint with white margin; frons brown, not blue-black; tegulae, basal half white, apical half monse-grey, not white with black central round ring; patagia mouse-grey edged with white, not white with kidney-shaped black ring; thorax white with four mouse-grey patches, not white with four greyish white patches ringed with steelblue. Abdomen, first segment brown, not greyish with three steel-blue patches ; rest of abdomen above steel-blue with an orange chevron on the fourth, fifth, and sixth segments and lateral orange longitudinal bands, not metallic blney purple with orange segmental rings._- Forewings less hyaline and with six bands of patches._Hindwings white, not hyaline with inner area white.

ㅇ. Also smaller; the hindwings three parts covered with dark grey blotches and abdomen steel-blue with lateral longitudinal orange bands.

Hab. Rio de Janeiro and neighbourhood (Petropolis).

1 ô, 1 ㅇ.

\section{Ecpantheria testacea spec. nov.}

§. Pectus pale cinnamon testaceons; palpi buff; frons black; head and thorax pale cinnamon testaceous, a blackish grey oval ring on the patagia and some blackish dots on thorax; abdomen above greyish steel-blne, basal and anal segments pale testaceous, a row of dorsal patches and lateral longitudinal bands orange.—-Forewing pale cinnamon testaceous, outer one-fourth more semihyaline, a large blackish stigma at apex of cell, five transverse bands of blackish grey rings._-Hindwing hyaline, except inner area whitish; inner area smoky brownish testaceous.

. Similar but paler and larger; forewing testaceous white with six transverse bands of cinnamon testaceons patches, no cellnlar stigma._-Hindwing testaceons white with a marginal and submarginal row of pale testaceous patches.

Length of forewing : o $24 \mathrm{~mm}$.; \& $30 \mathrm{~mm}$.

Hab. Pera: Poznza; La Oroya and La Union, Carabaya; Chanchamayo. 14 ठ의, 5 웅.

\section{Ecpantheria icasia trinitatis subspec. nov.}

8. Differs from icasia icasia by the absence of the black patches on the dorsal surface of abdomen, which are replaced by white bands.

ๆ. Differs by the absence of the dark rings to the white patches on the abdomen and paler markings on forewings.

Hab. Caparo and Belmont, Port of Spain, Trinidad.

41 ठे ठ, 1 ค. 


\section{Ecpantheria melanoleuca spec. nov.}

§. Pectns, legs, head and antennae sooty brown; palpi golden buff; thorax sooty brown, paler margins to tegulae and patagia; abdomen sooty brown, a testaceous central and orange lateral bands._- Forewing white, five broad irregular transverse bands of sooty brown coalescing blotches, the third and fourth forked from vein 6 to costa._- Hindwing white, two dark grey dots at tornus, a subapical one, and one in cell.

Length of forewing : $20 \mathrm{~mm}$.

Hab. Suncho Corral, Santiago del Esterro (J. Steinbach).

$1 \delta$.

\section{Ecpantheria oslari spec. nov.}

\section{б. Near albescens Hmpsn.}

Pectus black and white; inside of tibiae orange; frons black with central white line; vertex white; antennae white above, sooty beneath; tegnlae white with central black ring; patagia white with kidney-shaped black ring; thorax orange buff with central black ring; abdomen orange.—-Forewing white with seven transverse bands of coalescing monse-grey patches each with a black ring, the second and third band from base broken into two just below vein 3.-Hindwing satiny white with a costal band of pale sooty brown to just before termen.

Length of forewing : $18 \mathrm{~mm}$.

Hab. Asper Ranch, Brownsville, Texas.

1 ठे.

10. Apantesis fasciata pyrenaica subspec. nov.

§. Differs from fasciata fasciata by its bright crimson pectns and sides of chest and broad crimson collar. The forewing is entirely black except the white basal area, and has four narrow irregular zigzag white bands. The hindwing has the whole inner area yellow, not scarlet as in fasciata fasciata; the scarlet border is more than half obliterated, and there is a large extra black patch from costa to vein 2 across centre of wing.

Hab. Val d'Aras, Spanish Pyrenees, June 1907 (Mousquès).

1 ठे.

\section{Hypomolis palmeri spec. nov.}

§. Legs sooty grey; pectus scarlet; palpi and frons scarlet; frons, tegulae, and patagia dark lavender grey ; antennae sooty grey ; thorax dnll red in front, rest brownish bronzy olive; abdomen brick-red._- Forewing, costa scarlet with a black spot one-fifth from base, pale lavender grey with two black spots along subcostal vein ; a black spot on vein 8 one-sixth from termen, rest of wing bronzy apple green with a brownish lavender grey shade on disc, central two-thirds of inner area to vein 1 plum-black, from this plum-black area an elbowed dark line runs to vein 3 from basal end, and two parallel dark lines from apical end to vein 2 ; on the dise is an irregular dark line surrounding the lavender shade.-Hindwing salmoncolour.

Length of forewing: $17 \mathrm{~mm}$.

Hab. San Antonio, West Colombia, 5800 ft., December 1907 (M. G. Palmer). $2 \delta \delta, 4$ i + . 


\section{Palaeomolis garleppi spec. nov.}

§. Legs, pectns, head, and thorax cinnamon; antennae rufous ; abdomen paler cinnamon._- Forewing brownish cinnamon, a curved waved black transverse line one-third from base from costa to inner margin, a similar broader line from inner margin to lower angle of apex of cell where it forks, the inner fork reaching costa, the onter vein 10 ; beyond this a third waved transverse line from inner margin to costa one-fourth from termen.-Hindwing pale buffish cinnamon, an indistinct dusky cellular stigma.

Length of forewing : $13 \mathrm{~mm}$.

Hab. Rio Tanampaya, Bolivia, 1894 (Garlepp).

18.

\section{Palaeomolis hampsoni spec. nov.}

๙. Legs and head dull brownish red; antennae brown; thorax chocolate washed with mauve, abdomen salmon buff._- Forewing, costa, and nervures orange scarlet, inner area below vein 1, costal area between costa and subcostal, and a patch between veins 2 and 5 manve, onter marginal area broadly orange buff washed with brown, rest of wing bronzy grass green, some indistinct wavy dark lines on disc. Some specimens are browner, and have three distinct wavy discal lines.

Length of forewing : $16 \mathrm{~mm}$.

Hab. Santo Domingo, Carabaya, S.E. Peru (Ockenden).

15 oิ ô.

\section{Pygarctia fusca spec. nov.}

๙. Pectus and legs sooty grey; forecoxae pale crimson; head, tegulae, and antennae sooty brown, collar crimson; thorax sooty brown; patagia edged inwardly with crimson; abdomen salmon crimson.-Forewing sooty brown, crimson at base.—Hindwing semihyaline, brownish grey, darker towards outer margin.

ㅇ. Similar, but larger.

Length of forewing: ô $20 \mathrm{~mm}$. ; ㅇ $25 \mathrm{~mm}$.

IHab. Tucson, Arizona, May 19, 1903 (Type) (J. E. Oslar); San José, Costa Rica, September 1902 (Underwood).

2 oิ 0 , 1 우.

\section{Pygarctia oslari spec. nov.}

o. Pectus pink; head grey and pink; antennae black; thorax pale whitish buffy grey; tegulae and patagia slightly edged with pink; abdomen salmon crimson.—-Fore- and hindwing creamy whitish grey.

Length of forewing: $16.5 \mathrm{~mm}$.

Hab. Las Vegas, New Mexico, July 1902 (J. E. Oslar).

3 oे ô.

\section{Stenarctia abdominalis spec. nov.}

๙. Pectus pale crimson; legs sooty brown; head and antennae and thorax brownish cinnamon, black central spots on tegulae; abdomen much elongated, salmon-colour, a black spot on each side of segments 2 to 7 ; anal tuft very large, pale crimson; clasper tufts yellow.—-Forewing cinnamon brown, a black dot 
on costa two-fifths from base, and a second one above apex of cell, and one in middle of cell._-Hindwing paler buffish cinnamon brown.

Length of forewing: $16 \mathrm{~mm}$.

Hab. Moyamba, Sierra Leone, March 1903 (D. Cator).

1 oे.

\section{Chlorhoda thoracica spec. nov.}

o. Pectus crimson; legs crimson; tarsi ringed with black inside of tibiae, and coxae pale green; palpi crimson; antennae dark brown; head and thorax bright green; collar crimson; patagia broadly edged with crimson; abdomen crimson.- Forewing bright green; costa golden yellow, inner margin scarlet, at one-third from base and two-thirds from base a black streak abont $2 \mathrm{~mm}$. long runs into wing from costa and inner margin respectively (4 in all).- - Hindwing semihyaline, orange buff slightly washed with pale green on onter area.

+ . Differs in having the patagia only slightly edged with erimson, the green of forewing much deeper and more bluish, and the hindwing semihyaline crimson; fringe deep crimson, a black dot at tornus.

Length of forewing : of $21 \mathrm{~mm}$; ; $19 \mathrm{~mm}$.

Hab. La Oroya, Carabaya, S.E. Peru (Ockenden).

2 ôे $\hat{o}, 1$ 우.

\section{Seirarctia jacksoni spec. nov.}

๙. Pectus, head, and thorax sooty rufous brown; antennae white, pectinations rufous; abdomen whitish cinnamon with black transverse bands.-Forewings rufous, irrorated and banded with sooty black; a black cellular stigma._- Hindwings cinnamon pink, a sooty cellular stigma, and an interrupted semi-obsolescent submarginal sooty band.

․ Similar, but gronnd-colour of forewings cinnabar red; hindwings and abdomen salmon pink.

Length of forewing: ô $19 \mathrm{~mm}$. ; ㅇ $23 \mathrm{~mm}$.

Hab. Nairobi to Monnt Kenia, British East Africa (Jackson).

2 oิ oิ, 1 ㅇ․

\section{Turruptiana thursbyi spec. nov.}

o. Pectus, legs, and tegulae orange; thorax orange; patagia sooty black broadly edged with orange; abdomen black-brown with broad lateral crimson bands. - Forewings sooty black, basal one-fourth slightly variegated with whitish grey, median and postmedian waved transverse bands buffish grey white.Hindwing crimson, with broad black border not quite reaching tornus. One specimen has more white on forewing, and two others have the transverse bands dark grey.

Length of forewing: $15 \mathrm{~mm}$.

Hab. Valley del Lago Blanco, Chubnt, Patagonia (Thursby). 5 ơ ô.

20. Stidzaeras strigifera ockendeni subspec. nov.

ㅇ. Differs from s. strigifera Druce by the bright scarlet not orange-yellow head and tegulae, the almost absent strigilations on the forewing, the last three segments of abdomen being black above and below, only orange laterally, and in the brown-grey of outer area of hindwing being broader and running into orange-buff area in streaks. 
Length of forewing : $28 \mathrm{~mm}$.

Hab. La Union, Carabaya, S.E. Peru (Ockenden).

1 ㅇ․

\section{Mallocephala magna spec. nov.}

§. Pectus orange-brown; head and thorax brown; tegulae margined with orange; antennae buffish, pectinations brown; abdomen orange._-Forewing deep wood-brown; costa creamy buff._-Hindwing semihyaline white; basal two-thirds of inner margin orange; costa and two-thirds of outer margin dull brownish grey.

Length of forewing: $20 \mathrm{~mm}$.

Hab. Salta, North Argentina (J. Steinbach).

1 o.

22. Mallocephala brittoni spec. nov.

๙. Head, thorax, abdomen, and forewing brownish cream-colour._-Hindwing white; antennae pale brown.

Length of forewing: $15 \mathrm{~mm}$.

Hab. La Soledad, Entre Rios, Argentina, January 1899 (Miss E. A. Britton). 6 ठै 0 .

23. Mallocephala venata spec. nov.

๙. Pectus white; head and tegulae pale grey; antennae rufous; thorax white; abdomen orange, densely clothed with white hairs almost hiding orange. —-Forewing pale mouse-grey, with nervures all broadly white.-Hindwing white.

Length of forewing : $20 \mathrm{~mm}$.

Hab. Preto, Minas Geraës.

10 .

\section{Mallocephala insipida spec. nov.}

๙. Legs, pectus, and head clay-grey ; antennae rufous grey; thorax, abdomen, and forewing cinnamon clayish grey.—-Hindwing greyish white.

Length of forewing : $16 \mathrm{~mm}$.

Hab. La Gama, Argentina, November 1899.

4 ơ $\sigma^{*}$.

\section{Antarctia quadrata spec. nov.}

ㅇ. Nearest to honora Schans.

Differs by the paler foxy brown thorax and forewing, the latter sprinkled with golden scales; the abdomen is darker orange, and lacks the large terminal buff cushion._-Hindwing paler, and with basal half of inner area orange.

Length of forewing: $22 \mathrm{~mm}$.

$H a b$. Sapucay, Paraguay, September 2, 1901 (W. Foster).

1 우.

\section{Antarctia palmeri spec. nov.}

๙. Pectus and legs deep brown; head and thorax wood-brown; antennae buff, pectinations pale brown; abdomen orange-brown._- Fore- and hindwing greyish wood-brown.

‥ Much larger; pectus, legs, head, thorax, and forewing very deep woodbrown._- Hindwing paler; antennae pale brown; abdomen black-brown, each segment with a terminal belt of long thick orange hairs; a large buff anal cushion.

Length of forewing: ô $18 \mathrm{~mm}$; ㅇ $26 \mathrm{~mm}$. 


\section{$(178)$}

Hab. San Antonio, West Colombia, December 1907, 5800 ft. (M. G. Palmer); Popayan, Colombia (Lehmann); Coriente, Canca Valley, Torne, Cauca Valley, Febrnary 1907 (Paine and Brinkley); Bogota (Child); Guadalite, Candinamarca.

18 ơ ơ 19 우우.

\section{Antarctia thursbyi spec. nov.}

o. Pectns orange; legs brown, mixed with orange; head and antennae brown; thorax deep clay-grey ; tegulae mixed with orange; abdomen orange.—Forewing deep brown, densely powdered with orange scales.-Hindwing paler, also powdered with orange scales; base and inner area orange.

Length of forewing : $19 \mathrm{~mm}$.

Hab. Valley de Lago Blanco, Chubut, Patagonia (Thursby).

2 ồ ô.

\section{Antarctia vivida spec. nov.}

๙. Nearest to vulpina Hübn., but mnch brighter in colonr; pectus, head, thorax, and legs deep rufons brown; forecoxae orange; antennae black-brown; abdomen dark orange, with brown hairs intermixed on central segments._Forewing rufons brown; veins brownish buff._-Hindwing : basal one-third bright orange, outer two-thirds golden brown.

+. Larger, slightly paler, and the orange area on hindwing much smaller.

Length of forewing: ô $21 \mathrm{~mm}$; ; $30 \mathrm{~mm}$.

Hab. Caracas, Venezuela.

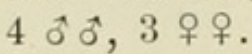

\section{Antarctia ockendeni spec. nov.}

ㅇ. Larger than gigantea Jones. Pectus, legs, head, and antennae sooty brown; tegulae orange mixed with brown hairs, rest of thorax and abdomen brown mixed with orange hairs, a golden buff anal cushion._- Forewing dark brown densely clothed with orange hairs._- Hindwing paler more semihyaline brown, sprinkled with shorter golden hairs and with a sooty cellular stigma and margino-submarginal band.

Length of forewing: $38 \mathrm{~mm}$.

Hab. Santo Domingo, Carabaya, S.E. Peru (Ockenden).

1 우.

\section{Antarctia klagesi spec. nov.}

․ Legs, pectns, head, and thorax chocolate wood-brown; abdomen and anal cushion orange._-Forewing chocolate wood-brown, slightly marbled with darker brown.—Hindwing wood-brown.

Length of forewing: $18.5 \mathrm{~mm}$.

Hab. Fonte Boa, Upper Amazons (S. M. Klages).

1 오.

\section{Antarctia marmorata spec. nov.}

$\hat{\jmath}$. Pectus, legs, and head dark brown ; antennae brown ; thorax and abdomen brownish clay-grey.—-Forewing brownish clay-grey, basal half blotched and marbled with varions-sized patches of darker sooty grey, a dark spot in outer half on vein 8.- Hindwing brownish clay-grey.

Length of forewing: $17 \mathrm{~mm}$.

Hab. Oconeque, Carabaya, S.E. Peru (Ockenden).

$10 \hat{\text { o }}$ 


\section{Antarctia steinbachi spec. nov.}

o. Deep dull brown all over, dise of both wings somewhat semihyaline, a sooty cellular stigma and two indistinct dark brown transverse bands one-fifth from outer margin; abdomen brown, orange on sides.

․ Larger deep rnfous brown, with one sooty transverse band one-fifth from outer margin ; abdomen and anal cushion orange, brown on centre of basal five segments.

Length of forewing: of $15-17 \mathrm{~mm}$; 우 $26 \mathrm{~mm}$.

Hab. Buenos Aires, 1 ơ (J. Steinbach); 1 oิ, 1 우 ? (Felder coll.); 1 우 Corrientes, Argentina, December 1898 (Maxwell Stuart).

\section{Antarctia haenschi spec. nov.}

ㅇ. Chocolate wood-brown all over, anal cushion buff.

Length of forewing: $2 \pi \mathrm{mm}$.

Larva black with three lateral rows of tufts of black bristly hairs; on each segment dorsally is a large transverse cushion of short, dense, soft hairs of a bright chestnut-red colour.

Hab. Santo Inéz, Ecuador (R. Haensch).

1 ㅇ, 2 larvae, and 2 cocoons.

\section{Antarctia fosteri spec. nov.}

${ }^{*}+$ ㅇ. Stone-buff all over, except hindwings, tinged with orange on abdomen; hindwings cream-colour.

Length of forewing : o $19 \mathrm{~mm}$. ; + $26 \mathrm{~mm}$.

Hab. Sapucay, Paragnay, 1900-1902 (W. Foster).

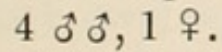

\section{Antarctia aurantiaca spec. nov.}

๙. Pectus, head, and thorax dull rufous orange; antennae rufuous brown; abdomen dnll rufous orange, anal segment and tuft whitish._- Forewing pale cinnamon greyish brown.—Hindwing greyish white.

+. Brilliant orange all over, hindwing slightly paler ; antennae rufous.

Length of forewing : $16-20 \mathrm{~mm}$.

Hab. Buenavista, E. Bolivia (J. Steinbach); Sapneay, Paraguay (IV. Foster); Province of Rio de Janeiro; Preto, Minas Geraës.

3 oิ ô, 4 우우.

\section{Antarctia cnethocampoides spec. nov.}

$\hat{\jmath}$. Legs, pectus, head, and thorax deep grey-brown, forecoxae orange ; abdomen deep grey-brown, laterally orange-__ Forewing mouse-grey, basal two-thirds darker, crossed by four irregular obsolescent dusky lines, subterminal and discocellnlar black spots._- Hindwing creamy white, with a few dusky dots; inner area buff.

Length of forewing : $16 \mathrm{~mm}$.

$H a b$. Salta, North Argentina (J. Steinbach).

$2 \delta^{2} \sigma^{*}$. 
37. Antarctia lehmanni spec. nov.

๙. Pectus, head, and forecoxae sooty grey; antennae brown, white shaft ; rest of insect greyish white, sides of abdomen orange.

Length of forewing : $20 \mathrm{~mm}$.

Hab. Popayan, Colombia (Lehmann).

1 oे.

\section{Antarctia felderi spec. nov.}

๙. Pectns, legs, head, and thorax bright rufous brown; antennae dull brown; abdomen orange.—-Forewing bright rufous brown, costa orange-buff. — Hindwing cream-white, inner area, costa, nervures slightly and submarginal line buffy brown.

․ Duller brown ; hindwings clay-brown; abdomen with buff lateral stripes.

Length of forewing : o $17 \mathrm{~mm}$; ; $21 \mathrm{~mm}$.

$H a b$. Rio de Janeiro.

1 ơ, 1 ㅇ.

\section{Antarctia peruviana spec. nov.}

o. Pectus, head, thorax, and forewings sooty brown-black; antennae yellowish brown; hindwing, basal half whitish, outer half sooty brown; abdomen dark grey.

Length of forewing : $17 \mathrm{~mm}$.

Hab. Agualani, Tinguri, and Rio Inambari, Carabaya, S.E. Pern (Ockenden). 26 ơ ô.

\section{Antarctia cajetani spec. nov.}

o. Uniform sooty chocolate; basal two-thirds of hindwings and veins of forewings whitish ; antennae rufous.

Length of forewing: $18 \mathrm{~mm}$.

Hab. Monte Video (Felder coll.).

1 ô.

\section{Proschaliphora butti spec. nov.}

๙. Pectus brown-grey; legs banded dark brown and yellow ; head, tegulae, and patagia orange; thorax pale lavender grey; abdomen orange, passing into buffy yellow towards the anal end.—- Forewing cream buff, fringe golden, two black spots at base, an antemedian straight and a postmedian curved transverse black band, a black discocellnlar stigma joined to postmedian band in $\widehat{\sigma}^{*}$, free in $\stackrel{+}{+}$; a submarginal row of seven black spots, two subterminal black spots on costa. Hindwing cream-buff, fringe yellow; a submarginal row of six black dots.

i larger.

Length of forewing : ô $15 \mathrm{~mm}$; i $17 \mathrm{~mm}$.

Hab. Foot of Nieuwreld Mountains, five miles N.W. of Beaufort West (Mrs. Butt); Weenen, Natal.

1 oิ, 1 ㅇ.

\section{Procanthea nivea spec. nov.}

. Silvery white, a sub-basal, antemedian, and postmedian, and a submarginal row of yellow spots on forewing, a black dot above vein 4 and one above vein 5 .

Length of forewing : $19 \mathrm{~mm}$.

Hab. Natal.

1 ․ 
43. Arctia caja parva subspec. nov.

o ․ Differs from all other forms by its small size. A whitish pink basal band to tegulae. - Forewing very deep brown, the white markings much narrower than in any other form.-Hindwing very deep scarlet.

- Length of forewing : $23 \mathrm{~mm}$.

Hab. Labrador.

2 oิ 0 , 1 ㅇ..

\section{Teracotona homeyeri spec. nov.}

๙. Pectus crimson; legs red banded with black; head brownish buff; collar crimson; thorax, tegulae edged narrowly with crimson internally, two black dots on shoulders, patagia bordered with crimson; abdomen, basal segment pale crimson, rest yellow ringed with black.___Forewing brownish buff; costa scarlet, a round black cellular stigma._- Hindwing pinkish white, a small dusky cellular stigma, inner area washed with pink.

․ Pectus and legs crimson; head cream buff; antennae black, basal $2 \mathrm{~mm}$. scarlet; collar broadly crimson; thorax cream buff, tegulae tipped and edged with brownish orange, two black spots at shoulders, patagia broadly edged with crimson ; abdomen, first segment crimson, rest orange._— Forewing salmon buff, fringe orange, inner margin scarlet, a black half-moon at apex of cell._-Hindwing buffish orange, inner area crimson, a large black half-moon at apex of cell.

Length of forewing : ơ $23 \mathrm{~mm}$. ; ㅇ $31 \mathrm{~mm}$.

Hab. Pungo Andongo, Angola, 1875 (Type) (A. von Homeyer); Manow, German East Africa.

1 oิ, 1 ㅇ․

45. Teracotona batesi spec. nov.

․ Pectus creamy whitish grey; legs clay-brown; head and thorax creamy whitish grey, tegulae narrowly edged with pale orange, a black spot on shoulders; abdomen orange, a central dorsal row of black spots ; antennae above white, apical one-third black.—-Forewing creamy whitish grey densely irrorated with dull brown._- Hindwing creamy white, two fuscons spots at tornus and one cellular stigma.

Length of forewing: $30 \mathrm{~mm}$.

Hab. Bityé, Ja River, Camaroons, $2000 \mathrm{ft}$., January to March 1907, dry season (Type), (G. L. Bates) ; Sierra Leone (Major Bainbridge). 2 우우.

\section{Teracotona buryi spec. nov.}

․ Differs from rodophaea Walk. in the ground-colonr of the wings being duller and browner irrorated and not banded with darker brown, and the hindwings having an irregular broken black submarginal band; abdomen crimson, while in rhodophaea the normal colour is orange.

Length of forewing: $24 \mathrm{~mm}$.

Hab. Gambaga, Gold Coast (Dr. Bury).

2 우오.

\section{Utetheisa pulchelloides salomonis subspec. nov.}

$\checkmark$ ㅇ․ Distinguished from $p$. pulchelloides by the great enlargement of the black and red patches in the forewings and the broad black border to hindwings in which is a round white spot. 
Hab. Solomon Islands, Guadalcanar, May 1901, and Guizo, November 1903 (A. S. Meek).

\section{7 ơ ô, 13 웅.}

48. Utetheisa pulchelloides stigmata subspec. nov.

of + . Differs from $p$. salomonis by the still wider black band to the hindwings and by having a large black patch at end of cell of same wings, and no white spot in black band.

$H a b$. Noumea, New Caledonia ; and Lifu, Loyalty Islands.

4 ơ ô $^{2}, 8$ 우 ( 1 ㅇ has forewings almost entirely red).

49. Utetheisa pectinata ruberrima subspec. nov.

o. Differs from pectinata pectinata by the great extension of red on forewings and the very wide black border of hindwings, in which is a white spot in black band.

Hab. Lifu, Loyalty Islands.

10 .

50. Utetheisa callima dilutior subspec. nov.

of $q$. This is the Central and East African subspecies of callima Swinhoe, and differs by having the cream-colour of the forewings much extended and the red bands narrower and paler and the band of the hindwings not regular owing to the white breaking in.

Hab. Slopes of Kilimandjaro, June 1905 (Jackson); Fort Johnston, Nyassaland, January-February 1896 (Dr. Percy Rendall); Mptapna, German East Africa ; Kissenyi, Lake Kivu, October 1907 (R. Grauer) (type); Ussuwi to Marienseen, Urundi, 1000-1800 m., June-July 1907 (R. Grauer).

23 oै ô, 18 우우.

\section{Utetheisa sumatrana spec. nov.}

๙. Head and thorax orange; abdomen white-Forewing orange-scarlet, a central cream-white band from base to within one-fourth of apex of cell, a round cream spot in black patch above it, a cream spot in black ring at apex of cell, vein 1 from base broadly cream, fringe white.-Hindwing semihyaline white. One male has some cream spots on disc.

Length of forewing : $19 \mathrm{~mm}$.

Hab. Deli, North-East Sumatra.

3 ơ ô.

\section{Utetheisa pulchelloides marshallorum snbspec. nov.}

tof. Differs from $p$. salomonis by its very large size, equalling large pulchella, by the strong diminution of the black markings and increase of the red markings, and by the normal dark border to the hindwing.

Hab. Marshall Islands, Oceania.

4 ô $0 \hat{0}, 5$ 우우.

\section{Axiopoeniella lasti spec. nov.}

+ . Differs from A. laymerisa in pectus, head, and thorax being of a sooty blackbrown, not pale wood-brown; in the first two segments of abdomen being blackbrown and the rest scarlet, not golden yellow; in the forewings being smoky 
black-brown above and below, not pale wood-brown above and golden orange or salmon bordered with brown below; the hindwings differ in having the basal area and a mnch wider border black and the rest of the wing dark crimson, not crimson scarlet.

Length of forewing : $21 \mathrm{~mm}$.

Hab. Madagascar (Last).

2 우오.

\section{Rhodogastria magnifica spec. nov.}

This fine species is in structure nearest to $R h$. bubo.

o. Pectus white; forelegs chocolate, forecoxae, middle pair and hind pair of legs dull orange ; palpi buff, a patch on middle and the third segment black; head white, two spots on frons black; thorax white, a black spot at base and one at apex of tegulae, two black spots on patagia, six black spots on thorax; abdomen, basal half above white, apical half crimson scarlet, a lateral row of black spots. Forewing, basal half white, three black spots at base, costa at base dilated into a very large vesicle $8 \mathrm{~mm}$. long by $5 \mathrm{~mm}$. wide, with a large transverse opening in it coloured black, outer half of wing semihyaline bluish white, a broad median transverse band clay-brown, apex of wing clay-brown reaching along costal area to base of vein 9 and on onter margin to beyond vein 5, nervures pale brown.Hindwing semihyaline white, tornus produced into a short tail.

Length of forewing : $36 \mathrm{~mm}$.

Hab. British East Africa.

1 t.

\section{Rhodogastria rothi spec. nov.}

Nearest to Rh. vidua.

๙. Pectus and legs pale crimson, outside of foretibiae and basal two-thirds of tarsi chocolate; head brown washed with pink, a black spot between antennae and another on vertex ; palpi black ; antennae black-brown ; collar and base of antennae crimson; thorax chocolate-brown, tegulae and patagia narrowly edged with crimson on inside, a black spot at apex of tegnlae, one on patagia and six on thorax; abdomen crimson._- Forewing deep chocolate-brown, disc semihyaline, base pink with two black dots.— Hindwing semihyaline, buffy rose, veins deeper rose, apex broadly chocolate, outer margin and inner area pale salmon-crimson.

․ Similar.

Length of forewing : $24-26 \mathrm{~mm}$.

Hab. Warri, River Niger, May 1897 (Dr. Roth).

4 ơ 0 ô, 3 우우.

\section{Rhodogastria roseomarginata spec. nov.}

o. Pectus and inside of legs bright carmine, outside of fore- and middle legs chocolate, of hindlegs carmine; palpi carmine, spotted and tipped with black ; head and thorax cinnamon wood-brown with usual twelve spots and crimson collar ; abdomen dark carmine, basal segment cinnamon wood-brown.-Forewing cinnamon orange-brown, disc semihyaline, beyond apex almost clear hyaline.Hindwing almost hyaline ; nervures, margin, and inner area brownish rose.

Length of forewing : $24 \mathrm{~mm}$.

Hab. Ogrugu, Niger; Kiongo, south of Rovima, March to May 1898 (Reimer). 5 ơ ô. 


\section{Rhodogastria affinis spec. nov.}

๙. Differs from roseomarginata by its duller brown colour, in the dise being semihyaline and not having the part beyond the cell vitreous, in the absence of the uniformly wide rose margin to the hindwing, which has a broad brown apical patch and a narrow grey-brown margin. The forewing is also much wider. Abdomen brownish rose.

\section{Hab. South Africa.}

Sir George Hampson has nnited under Rhodogastria astreas (Drury) a very heterogeneons mass of species, both African and Asiatic. He afterwards reinstated bauri Möschl. as a species, but quite failed to see that none of the African Rhodogastria of this group were synonymons with astreas or any of the other Asiatic forms. The African forms are as follows :

Rh. bauri Möschl., Sonth Africa.

" madagascariensis Boisd., Madagascar.

", vitrea Plötz, Niger to Natal.

", roseomarginata spec. nov., Nigeria and East Africa.

" affinis spec. nov., South Africa.

\section{Rhodogastria crokeri novobritannica subspec. nov.}

oㅇ․ Differs from c. crokeri by its more dusky and darker forewings, by the entire absence of the hyaline spot in cell, by the semihyaline, not hyaline, disc beyond cell, and by the semihyaline white hindwings margined with clay-brown, not entirely clay-grey hindwings. The black spots on tegulae are much larger, occupying one-third of each tegula ; the whole basal third of the patagia is black, and the black spots on thorax are much larger.

Hab. New Britain.

1 oิ, 1 ‥

59. Rhodogastria crokeri salomonis subspec. nov.

․ Differs from $c$. crokeri in the basal fourth of the antennae being crimson, the black spot on frons almost occupying the whole frons, the black spot on tegulae enlarged to half the size of tegulae, the patagia being black margined outwardly with white, and the six black spots on thorax much enlarged. The ground-colour of forewing is also much darker.

Hab. Solomon Islands: Guadalcanar (Woodford); Guadalcanar, May 1901 (A. S. Meek) ; Florida, January 1901, Isabel, June-July 1901, Guizo, November 1903 (A. S. Meek); Tulagi (S. M. Woodford).

6 ơ 0 , 4 우 우.

Isabel specimens seem to have a more magenta-coloured abdomen and tarsi.

\section{Rhodogastria omissa spec. nov.}

This species seems to have been completely overlooked.

o. Coloured as in astreas Drury, but the forewing broad and rounded as in roseibarba Druce. Hindwing tailed as in arthus-bertrand, but the tuft on inner area is smaller and narrower and pale buff-primrose in colour. Abdomen, first segment dull pink, second segment white, three following segments primrose buff, last two segments crimson. 
․ Similar in colour to $ᄋ$ astreas, but much larger and broader, and hindwing produced into short tail at tornus.

Length of forewing : o $33 \mathrm{~mm}$; क $37 \mathrm{~mm}$.

Hab. Khasia Hills, Assam (native collectors).

18 ô $\sigma^{\circ}, 10$ 웅.

\section{Rhodogastria piepersi Snell.}

Nearest to arthus-bertrand, but not all identical with it, as the author afterwards asserted.

o. Differs in having head and thorax dark monse-grey, not pale whitish grey, in forewings being blunter and broader, and the dise being entirely semihyaline, not only beyond cell._-Hindwing is semihyaline mouse-grey, not white almost opaque; the tuft on inner area is much smaller, and brownish grey-buff, not white. Abdomen, first segment dark mouse-grey, second pale carmine, next three golden buff, and last two carmine.

ㅇ․ Very similar to ㅇ arthus-bertrand, but thorax and head darker, both wings more semihyaline, and the tail much less developed.

Length of forewing: ô $27 \mathrm{~mm}$; 우 $26 \mathrm{~mm}$.

Hab. Tawaya, north of Palos Bay, Celebes, August-September 1896 (W. Doherty); Buton, April 1906 (Dr. Martin); South Celebes, Angust-September 1891 (W. Doherty); Dongola, south of Palos Bay, Celebes, 1896 (W. Doherty); Sula Mangoli, October 1897 (W. Doherty); ? (Felder coll.).

9 ô 0 , 3 우 ㅇ.

\section{Rhodogastria fumida pallida subspec. nov.}

ơ ㅇ․ Differs from $f$. fumida by the almost buffy grey not wood-brown groundcolour of the wings, some males even being greyish white.

Hab. Dili, Timor, May 1892 (W. Doherty).

5 ธิ ธิ, 1 ㅇ.

63. Rhodogastria astreas hainana subspec. nov.

๙. Smaller than $a$. astreas, darker grey disc of forewings less semihyaline.

‥ Larger, paler, more isabelline.

Hab. Cheng-Mai, Hainan, August 1902 ; Cochin China (Felder coll.).

2 ô 0 , 6 우 우.

64. Rhodogastria astreas curtisi subspec. nov.

๙. Differs from a. astreas in its smaller size, deep grey colour, and more opaque wings.

․ Differs in its smaller size and dark colour, being quite like the $\hat{o}$.

Hab. Penang, March 1897 (Curtis).

2 ơ $0 \hat{0}, 3$ 우 우.

65. Rhodogastria lactea spec. nov.

‥ Pectus cream-white; legs outside fore pair buffy rufous, other two pairs whitish, inside all three pairs dull crimson; head and thorax pale brownish cream 
with twelve black dots; antennae crimson; abdomen crimson._- Forewing creamy white, disc almost vitreons._-Hindwing semihyaline white.

Length of forewing : $22 \mathrm{~mm}$.

Hab. Minbu, Burma.

1 ㅇ.

66. Rhodogastria bipartita spec. nov.

๙. Pectus orange; legs orange, whitish outside; palpi and antennae black; head and thorax white with black spots; abdomen orange._- Forewing white, two black spots at base, disc semihyaline bejond cell._- Hindwing shaped as in arthus-bertrand, brownish orange.

Length of forewing: $27 \mathrm{~mm}$.

Hab. Tanta (Taveta), East Africa, July 1891.

1 oे.

67. Rhodogastria kuehni spec. nov.

๙. Pectus white; legs buff, whitish ontside; head white; antennae orange yellow ; collar and anterior part of thorax orange yellow ; rest of thorax white witb eight black dots; abdomen orange yellow._- Forewing semihyaline white, costal area and nervure pale testaceons.—-Hindwing semihyaline white.

Length of forewing : $29 \mathrm{~mm}$.

Hab. Dammer Island, December 1898 (H. Kühn).

$2 \hat{o} \hat{\sigma}$; one bad specimen in British Museum from Tenimber.

\section{Rhodogastria alberti spec. nov.}

๙. Pectus white with two black spots; legs crimson, white at sides; head and thorax white with ten black spots, collar and front of thorax crimson; antennae crimson; abdomen crimson._-Forewing white, two black spots at base, disc strongly semihyaline._-Hindwing semihyaline white, inner area pale greyish buff.

Length of forewing : $33 \mathrm{~mm}$.

Hab. Cedar Bay, Queensland (A. S. Meek); Cairns, North Queensland.

4 ธิ ธิ.

69. Diacrisia porthesioides spec. nov.

${ }^{\circ}$. Pectus white; head buff; thorax pale orange; abdomen white; antennae whitish.___Forewing buff.___Hindwing white.

Length of forewing: o $19 \mathrm{~mm}$., ㅇ $25 \mathrm{~mm}$.

Hab. Sikkim, May 1889 (J. G. Pilcher).

2 oิ 0 , 3 우우.

70. Neritos eximius spec. nov.

$\hat{o}$. Pectus pink; palpi and head black; antennae fuscons; thorax black, tegulae scarlet with black patch, patagia scarlet; abdomen scarlet, anal segment black, clasper tufts yellow.- Forewing black, a broad scarlet central band from base to vein 2, three longitudinal hyaline patches between veins 2 and 6 .—-Hindwing almost hyaline, basal half of inner area pale crimson, a broad margin half width of wing black.

Length of forewing : $13 \mathrm{~mm}$.

Hab. La Oroya, Carabaya, S.E. Peru (Ockenden).

1 o. 


\section{Elysius strigillata spec. nov.}

$\hat{o}$. Pectus orange ; palpi, antennae, and head black; thorax black, tegulae and apical half of patagia orange; abdomen black, last two segments pale orange._Forewing black crossed by abont twenty-six irregular silvery buff transverse lines, giving the wing the appearance of alternate black and pale strigillation. Hindwing black.

Length of forewing : $22 \mathrm{~mm}$.

Hab. La Union, Carabaya, S.E. Peru (Ockenden).

1 ô.

\section{Zatrephes atrata spec. nov.}

๙. Pectus buff; legs pale rufous brown; rest of insect above entirely blackbrown; a three-lobed hyaline patch at end of cell on forewing.

Length of forewing: $18 \mathrm{~mm}$.

Hab. Christianeburg, Rio Demerara, British Guiana.

1 o.

This species is close to miniata Rothsch.

\section{Robinsonia klagesi spec. nov.}

९. Pectus white; palpi dark grey and white; antennae fuscous; head buff; thorax monse-grey, tegulae and patagia white bordered with mouse-grey ; abdomen orange with white central dorsal line, anal segment whitish._- Forewing brownish mouse-grey; a broad elbowed central white band one-third the width of the wing reaches from base to costa just before termen, inner margin white.-Hindwing white.

Length of forewing: $19 \mathrm{~mm}$.

Hab. San Esteban, Venezuela, July 1909 (S. M. Klages).

1 i .

\section{Automolis fuliginosa spec. nov.}

§. Pectus whitish; legs and head black; antennae fuscous; thorax black, a white spot at base of tegulae and patagia and a white patch at juncture of abdomen; abdomen above black; a white dot on segments 1,5 , and 6 , below white.—-Forewing, sooty grey at base; nervures and terminal area between vein 5 and costa sooty black.-Hindwing sooty black, semihyaline whitish between vein 2 , basal half of inner area white.

Length of forewing : $20 \mathrm{~mm}$.

Hab. Fonte Boa, Upper Amazon (S. M. Klages).

1 \&.

75. Glaucostola underwoodi spec. nov.

б. Pectus and legs grey; head deep orange; antennae and thorax grey; abdomen grey, underside of anal segment orange._—_Forewing lavender grey.— Hindwing brownish black glossed with purple, a broad median wedgeshaped hyaline bluish white reaching from base almost to outer margin,

Length of forewing : $19 \mathrm{~mm}$.

Hab. Costa Rica (Underwood).

$1 \delta$. 
76. Amastus picata spec. nov.

ๆ. Pectus pale yellow; head and tegulae white; antennae fuscous; patagia white with black basal band reaching half-way to apex ; thorax pale yellow ; abdomen pale yellow, last three segments greyish white.-Forewing dark sooty brownish grey, more hyaline towards base, a black discocellular stigma and a median and postmedian zigzag white line.—-Hindwing semibyaline grey, a nebular greywhite submarginal line.

Hab. Huancabamba, East Peru (E. Böttger).

1 \&.

7\%. Halisidota notodontina spec. nov.

§. Pectus and legs pale buff; antennae pale brown; head and thorax buff; abdomen orange buff._—_Forewing buff irrorated, banded and spotted with lavender grey-brown._-Hindwing yellow buff, a large patch of greyish brown from just below tornus to vein 5 .

Length of forewing : $2 \tau \mathrm{mm}$.

Hab. Huancabamba, East Peru (E. Böttger).

$1 \delta$.

\section{Ischnocampa pellucida spec. nov.}

§. Legs, pectus, and antennae grey-brown; head, thorax, and abdomen browngrey._- Forewing hyaline powdered and irrorated with brown and yellow specks. -Hindwing similar but less densely speckled, and the specks are grey-brown, hardly mixed at all with yellow.

Length of forewing: $15 \mathrm{~mm}$.

Hab. Dominica, February 1905 (E. A. Agar), Valencia, Venezuela. 2 oิ 0 , 3 우. 


\section{$2 \mathrm{BHL}$ Biodiversity Heritage Library}

Rothschild, Lionel Walter Rothschild. 1910. "Descriptions of new species of Arctianae in the Tring Museum." Novitates zoologicae : a journal of zoology in connection with the Tring Museum 17, 172-188.

https://doi.org/10.5962/bhl.part.13690.

View This Item Online: https://www.biodiversitylibrary.org/item/22248

DOI: https://doi.org/10.5962/bhl.part.13690

Permalink: https://www.biodiversitylibrary.org/partpdf/13690

\section{Holding Institution}

Natural History Museum Library, London

\section{Sponsored by}

Natural History Museum Library, London

\section{Copyright \& Reuse}

Copyright Status: Public domain. The BHL considers that this work is no longer under copyright protection.

This document was created from content at the Biodiversity Heritage Library, the world's largest open access digital library for biodiversity literature and archives. Visit BHL at https://www.biodiversitylibrary.org. 